\title{
REFUGIADOS DE BENTO RODRIGUES: \\ O DESASTRE DE MARIANA, MG
}

REFUGEES FROM BENTO RODRIGUES: THE DISASTER OF MARIANA - MG

\section{Géssica Auxiliadora da Silva}

turop@bol.com.br

Universidade Federal de Ouro Preto (UFOP), Ouro Preto/MG, BRASIL

\section{Diego Luiz Teixeira Boava}

profboava@yahoo.com.br

Universidade Federal de Ouro Preto (UFOP), Ouro Preto/MG, BRASIL

\section{Fernanda Maria Felício Macedo}

profamacedo@yahoo.com.br

Universidade Federal de Ouro Preto (UFOP), Ouro Preto/MG, BRASIL

\section{Resumo}

Neste trabalho são analisados oito depoimentos dos sobreviventes do rompimento da barragem da Samarco Mineração em Bento Rodrigues (Mariana, MG). São quatro mulheres e quatro homens que vivenciaram as consequências de perderem suas casas, entes queridos, bens, terras etc. Para tal, fez-se uso da fenomenologia e do método fenomenológico. Para entender a fenomenologia, é necessário compreender que o homem é um "doador de sentido" ao mundo. Logo, o seu método centra-se no homem, especificamente na análise do significado e relevância da experiência humana, buscando captar as essências do que ele vivenciou. Os depoimentos foram coletados em locais em que os moradores foram alojados nos dias subsequentes ao rompimento. Objetiva-se compreender o acontecimento a partir de quem o vivenciou, por isso, a coleta dos depoimentos nos dias seguintes ao desastre.

Palavras-chave: Desastre. Samarco. Mariana. Fundão. Bento Rodrigues.

\begin{abstract}
In this work, eight testimonies of the survivors from the rupture of the Samarco Mining dam in Bento Rodrigues (Mariana - MG) were analyzed. There are four women and four men who have experienced the consequences of losing their homes, loved ones, property, land, etc. For this, one makes use of phenomenology and the phenomenological method. To understand phenomenology, it is necessary to understand that man is a "giver of meaning" to the world. Therefore, its method focuses on man, specifically on the meaning analysis and relevance of human experience, seeking to capture the essences of what the man has experienced. The testimonies were collected in places wherein the residents were housed in the days subsequent to the dam rupture. It is intended to understand the event from the person who experienced it, for this reason, the testimonies collection in the days subsequent the disaster.
\end{abstract}

Keywords: Disaster. Samarco. Mariana. Fundão. Bento Rodrigues. 


\section{Introdução}

A prática de extração mineral implica em aspectos positivos e negativos para as localidades que vivenciam esta rotina de atividades desenvolvidas por empresas do ramo. Dentre questões benéficas, pontua-se a geração de emprego, renda, movimentação econômica, elevada arrecadação municipal, ações de 'responsabilidade' social e ambiental, entre outros aspectos derivados de tais pontos. Além disso, os minérios são a matériaprima de principais bens duráveis e de consumo que a sociedade necessita. Por sua vez, no tocante às implicações negativas, destacam-se problemas de poluição, desmatamento, assoreamento de rios, contaminação do solo e água por produtos químicos e a produção de rejeitos.

Assim, a atividade de extração mineral representa um balanço de custo-benefício para as localidades que possuem esta prática, sendo que, na maior parte das vezes, os pontos positivos da extração são significados como superiores aos impactos ambientais causados, já que com o desenvolvimento tecnológico as empresas do setor afirmam que trabalham com o mínimo impacto ambiental possível, divulgando uma cultura que associa extrativismo e 'sustentabilidade'. Desta forma, o dano ambiental é apresentado com um custo mínimo, que se pagaria pelos benefícios dos minérios extraídos. Todavia, o desastre ambiental causado pelo rompimento da barragem de rejeitos denominada Fundão, ocorrido em novembro de 2015 no município de Mariana-MG, evidencia que o discurso associando 'sustentabilidade' e a extração mineral é frágil, e os custos pagos pelos benefícios econômicos da extração mineral são, de fato, elevados. A barragem é controlada pela Samarco Mineração, um empreendimento das maiores empresas de mineração existentes, a Vale S.A. e a BHP Billiton.

Em face desse cenário, o presente artigo visa investigar o rompimento da barragem de Fundão na perspectiva de quem vivenciou o mesmo. O foco do trabalho centra-se no sujeito, já que o mesmo é o ator capaz de significar e evidenciar os reais contornos envolvendo este desastre ambiental e suas consequências. Para isso, emprega-se como referencial teórico metodológico a fenomenologia, que fundamenta seus pressupostos na consciência intencional do sujeito e sua experiência de vida. Nesta ótica de investigação, o fenômeno fala por si mesmo.

Neste trabalho são analisados oito depoimentos dos sobreviventes do rompimento da barragem da Samarco
Mineração em Bento Rodrigues (Mariana, MG). São quatro mulheres e quatro homens que vivenciaram as consequências de perderem suas casas, entes queridos, bens, terras etc. Para tal, como mencionado, fez-se uso da fenomenologia e do método fenomenológico. Os depoimentos foram coletados em locais em que os moradores foram alojados nos dias subsequentes ao rompimento.

Divide-se o texto em introdução, seguida por uma breve apresentação dos pressupostos fenomenológicos que norteiam o desenvolvimento deste trabalho, depois tem-se a descrição do fenômeno, elaborada nos tópicos: caracterização de Mariana, caracterização da Samarco, caracterização de Bento Rodrigues. Uma vez apresentados a base teórica e o fenômeno a ser estudado, descrevem-se os procedimentos metodológicos para coleta e análise dos dados. Por fim, tem-se a interpretação dos relatos e as considerações finais. Não são efetuadas inferências sobre as causas ou responsabilização de culpados, tão somente descrição dos acontecimentos e caracterizações de cunho geral sobre a cidade de Mariana, a Samarco e o povoado devastado.

O título do trabalho revela o que, de fato, os moradores se tornaram: refugiados. Refugiados, pois o refugiar-se significa busca por segurança a partir de um deslocamento. Neste caso, forçado por um desastre. O próprio termo desastre carrega em si uma gama de significados. Neste caso, uma ação (ou inação) que produziu um colapso em uma estrutura (barragem) construída próxima a um povoado, de efeitos catastróficos (mortes, destruição).

Objetiva-se compreender o acontecimento a partir de quem o vivenciou, por isso a coleta dos depoimentos nos dias seguintes ao desastre. Caso os depoimentos fossem coletados na presente data, haveria muitos vieses, pois a superestrutura (governos, Samarco, justiça etc.) teria agido sobre os atingidos, tirando-lhes a objetividade ao falar sobre suas vivências. Afinal, na atualidade, Bento Rodrigues é apenas lembrança, o lugar em que moraram e viviam.

\section{Fenomenologia}

Edmund Husserl cria a fenomenologia como um movimento, uma atitude de análise, capaz de atribuir rigor ao pensamento filosófico. Sua primeira apresentação ocorre no livro 'Investigações Lógicas' publicado em dois volumes, em 1900 e 1901. 
Nos dizeres de Husserl (2006, p. 27), a fenomenologia permite a remoção de barreiras cognitivas inerentes à essência de todo modo natural de investigar, diversificando a direção unilateral própria do olhar até obter-se o livre horizonte dos fenômenos 'transcendentalmente' purificados.

Nesta perspectiva, a fenomenologia busca acessar a essência do fenômeno, isto é, a parte encoberta por aquilo que se apresenta no formato de aparência. Desta forma, o movimento de estudo é partir para aquilo que é dado à consciência do sujeito, considerando suas experiências vividas.

Vale destacar, no entanto, que o dado proveniente da experiência não se reduz a experiência sensível, mas aquilo que é dado à consciência a partir da intuição. Para Bochenski (1971, p. 45-46), a intuição fenomenológica aparece à primeira vista como se fosse algo muito sensível, mas é de fato um movimento de pensamento que permite ver além da aparência do objeto.

Esse movimento da intuição fenomenológica é fundamentado na proposta de Husserl de 'ir às coisas mesmas', a partir do qual se tem um resgate do objeto, à procura de exprimir aquilo que é dado diretamente na consciência. A consciência é, portanto, originária e intencional. 'Toda consciência é consciência de algo' (HUSSERL, 1988).

Tem-se, assim, que na abordagem fenomenológica, o sujeito e sua consciência intencional consistem no foco de atenção principal do pesquisador. $\mathrm{O}$ sujeito vem ao mundo e, neste, significa a sua existência, atribuindo e construindo relação e significados aos fenômenos que darão origem às suas experiências de vida. A pesquisa fenomenológica parte, portanto, da compreensão do viver e não de definições ou conceitos, e é uma compreensão voltada para o perceber.

Neste ponto, justifica-se o porquê do emprego da fenomenologia no estudo do rompimento da barragem de Fundão em Mariana e suas consequências para Bento Rodrigues e demais ambientes e comunidades. Pretendese neste trabalho deixar o fenômeno falar por si mesmo, dar voz a quem de fato vivenciou a questão em uma perspectiva aberta, sem hipóteses e preconcepções, sem o uso de uma teoria predefinida, buscando comprovar suas bases teóricas. As dimensões deste fenômeno não apresentam precedentes equivalentes na história e merecem ser interpretados como algo que transcende o que já se sabe sobre organizações, mineração, politicas ambientais, tem-se que atribuir voz ao novo.
A vertente fenomenológica confere abertura a um conhecimento novo, isento de conceitos e préconcepções baseadas em estudos objetivos, além de enfatizar a descrição da experiência humana tal como ela é, sem demais explicações causais. Trata-se de descrever o fenômeno.

Vários conceitos-chave estão relacionados à fenomenologia enquanto um referencial de busca da essência dos fenômenos. Diante disso, o quadro 1 apresentado a seguir elenca, em caráter introdutório, alguns deste conceitos, com a finalidade de evidenciar os fundamentos envolvidos na análise das experiências de vida descritas pelos refugiados de Bento Rodrigues.

Quadro 1. Conceitos fundamentais da fenomenologia

\begin{tabular}{|c|c|}
\hline \multicolumn{2}{|c|}{ Conceitos fundamentais da fenomenologia } \\
\hline $\begin{array}{l}\text { Ir às coisas } \\
\text { mesmas }\end{array}$ & $\begin{array}{l}\text { Retorno às origens, estabelecimento } \\
\text { de um contanto original com o objeto, } \\
\text { procurando exprimir aquilo que é dado } \\
\text { diretamente na consciência. }\end{array}$ \\
\hline $\begin{array}{l}\text { Consciência } \\
\text { Originária }\end{array}$ & $\begin{array}{l}\text { O homem a partir de sua consciência doa } \\
\text { sentido ao mundo. }\end{array}$ \\
\hline Intencionalidade & $\begin{array}{l}\text { Toda consciência é consciência de algo, } \\
\text { ou seja, o homem volta à consciência } \\
\text { para objetos que se dão a conhecer. }\end{array}$ \\
\hline Fenômeno & $\begin{array}{l}\text { Aquilo que aparece a consciência se } \\
\text { revelando por si mesmo. }\end{array}$ \\
\hline Eidos/ Essência & $\begin{array}{l}\text { Constitui a unidade da multiplicidade, } \\
\text { aquilo que permanece imutável mesmo } \\
\text { com mudanças. Faz com que o objeto } \\
\text { seja o que é e não outra coisa. }\end{array}$ \\
\hline Noesis/noema & $\begin{array}{l}\text { Noesis - ato; Noema - objeto } \\
\text { correspondente ao ato. }\end{array}$ \\
\hline Intuição & $\begin{array}{l}\text { Instrumento do conhecimento, } \\
\text { equivalendo a visão intelectual do objeto } \\
\text { que se é dado. }\end{array}$ \\
\hline Mundo natural & $\begin{array}{l}\text { O mundo externo e comum às pessoas, } \\
\text { nas quais os objetos se localizam e } \\
\text { adquirem existência. }\end{array}$ \\
\hline Atitude Natural & $\begin{array}{l}\text { O homem lançado ao mundo permanece } \\
\text { imerso no mesmo aceitando todas as } \\
\text { suas múltiplas facetas como verdades } \\
\text { incontestáveis. }\end{array}$ \\
\hline Redução & $\begin{array}{l}\text { Prática fenomenológica que envolve a } \\
\text { suspensão da atitude natural, colocando o } \\
\text { mundo e o teórico entre parênteses para } \\
\text { se chegar ao eidos do fenômeno. }\end{array}$ \\
\hline
\end{tabular}

Fonte: Boava (2012, p. 112-113) 
Diante desses conceitos, tem-se que neste estudo buscase efetuar uma pesquisa fenomenológica estrita. Isso porque, conforme observa Giorgi (2006), o número de pesquisadores no domínio das ciências sociais que estão empregando alguma variante do método fenomenológico tem aumentado, mas muitos estudos não conhecem os postulados fenomenológicos. Em seu trabalho, o autor faz uma análise de várias investigações precedentes, com vistas a discutir tais aspectos. Giorgi (2006) realça que a investigação que utiliza fenomenologia requer como pano de fundo: a filosofia fenomenológica, que não coaduna com critérios empíricos. Assim, a fenomenologia não é contra o empirismo, mas sim maior que ele, pois seu método interroga fenômenos que não são redutíveis a fatos. Afirma o autor:

[...] a pesquisa fenomenológica científica ainda não atingiu a maioridade. Infelizmente, acredito que os resultados encontrados aqui são típicos. Os princípios básicos da fenomenologia são frequentemente citados corretamente, mas eles não são totalmente conhecidos nem sempre são aplicadas corretamente. Assim, ao aproximar-se de pesquisa em ciências sociais com títulos fenomenológicos, é preciso ser cauteloso quanto ao que será encontrado (GIORGI, 2006, p.360).

O que Giorgi (2006) quer dizer é que a pesquisa fenomenológica empírica necessita da filosofia fenomenológica, pois este saber é o responsável pela própria constituição das ciências particulares.

Conforme Chauí (2005, p. 229-231), a constituição das ciências humanas como ciências específicas, consolidouse a partir das contribuições da fenomenologia, do marxismo e do estruturalismo, que provocaram uma ruptura epistemológica e uma revolução científica no campo das humanidades. Assim, a fenomenologia contribui com a questão ao possibilitar que fosse feita a distinção rigorosa entre a essência naturez̧a e a essência homem. A seguir, permitiu que o homem fosse distinguido em relação a outras essências diversas: $\mathrm{O}$ psíquico, o social, o histórico, o cultural. Ou seja, foi a fenomenologia que permitiu a delimitação e definição dos objetos das ciências humanas.
Desta forma, fundamentado neste referencial fenomenológico de atenção direcionada ao sujeito, sua consciência intencional e experiência de vida, o presente trabalho visa analisar os refugiados de Bento Rodrigues, atingidos pelo desastre ambiental causado pela mineradora Samarco, apreendendo a essência de seus relatos.

Dando sequência a estrutura do estudo, descreve-se nos tópicos subsequentes o fenômeno compreendido como rompimento da barragem de Fundão pertencente a Mineradora Samarco atuante em Mariana-MG e suas consequências para Bento Rodrigues.

O fenômeno é um elemento de destaque na fenomenologia, já que o próprio termo deriva dos vocábulos gregos Phainomenon ('discurso sobre aquilo que se mostra como é') e logos (ciência ou estudo). Etimologicamente fenomenologia é o estudo do fenômeno, tudo que o aparece, que se manifesta ou se revela por si mesmo (MOREIRA, 2002, p. 63).

Masini (1989), reforçando, apresenta a fenomenologia como tendo, enquanto objeto de estudo, o próprio fenômeno, ou seja, as coisas mesmas e não o que se diz delas. Logo, na presente investigação, tal fenômeno é evidenciado em toda a sua conjuntura, considerando para tal as descrições da cidade de Mariana, da mineradora Samarco e de Bento Rodrigues apresentadas a seguir.

\section{Caracterização socioeconômica de Mariana, MG}

Situada a $110 \mathrm{~km}$ de Belo Horizonte e $12 \mathrm{~km}$ de Ouro Preto, Mariana é uma cidade turística integrante do chamado Circuito do Ouro, um conjunto de cidades coloniais da região central de Minas Gerais. Porém, a atividade econômica principal é a mineração. No município, existem jazidas de ferro, ouro, manganês, quartzito, gnaisse, esteatito e bauxita. A Samarco Mineração e a Vale exploram o minério de ferro e ferro-manganês, sendo as maiores empregadoras e recolhedoras de impostos.

A Universidade Federal de Ouro Preto mantém em Mariana dois campi, com os cursos de graduação em Administração, Economia, História, Letras, Serviço Social, Pedagogia, e Jornalismo, além de mestrados em Economia, Jornalismo, Educação e História, sendo que esse curso também oferta doutorado. No total, são aproximadamente 2500 alunos, 35 técnico- 
administrativos e 150 professores, com significativa participação na movimentação da economia local, além de desenvolvimento de projetos de pesquisa e extensão de natureza variada sobre a realidade local.

O turismo no município constitui-se fonte secundária de recursos, sendo desenvolvido em função dos museus, igrejas, casario colonial, carnaval, minas desativadas, cachoeiras etc. existentes no local. Ou seja, devido aos patrimônios cultural, histórico e imaterial. A distribuição dos turistas por Mariana é desigual, sendo predominante na sede e no distrito de Passagem de Mariana (no meio do caminho entre Ouro Preto e a cidade). Tem-se ainda como atrativo, o chamado trem da Vale, ligação ferroviária entre Mariana e Outro Preto para turistas (linha que foi restaurada e é operada pela empresa). Em outros distritos tem-se o artesanato e produção de licores, quitutes, doces etc.

A evolução populacional se deu em função da exploração do minério de ferro, conforme a tabela a seguir:

Tabela 1 . evolução da população de Mariana

\begin{tabular}{|l|l|}
\hline Ano & População \\
\hline 1971 & 24.786 \\
\hline 1980 & 29.401 \\
\hline 1991 & 38.180 \\
\hline 2000 & 46.170 \\
\hline 2010 & 54.219 \\
\hline 2015 (estimativa IBGE) & 58.802 \\
\hline
\end{tabular}

Fonte: IBGE (2016)

A partir dos anos 1970, com a implantação da Samarco Mineração e da mineradora Samitri; e dos anos 1980 com a operação da Vale, houve expressivo aumento populacional, o que acabou reconfigurando a cidade.

Outro aspecto relevante do município é em relação ao Produto Interno Bruto (PIB). De elevado valor, mas com distribuição desigual de riqueza, conforme quadros 2 e 3. Deste modo, gerou-se na cidade $\mathrm{R} \$$ 6,5 bi em 2013, o que resulta em um PIB per capita aproximado de $\mathrm{R} \$ 115$ mil, sendo esse último resultado o responsável por fazer de Mariana a quinta colocada no estado de Minas Gerais e trigésima primeira colocada no Brasil em tal quesito.

Tabela 2 . evolução do PIB a preços correntes

\begin{tabular}{|c|c|}
\hline Ano & PIB (R\$ bi) \\
\hline 2010 & 3,697 \\
\hline 2011 & 5,729 \\
\hline 2012 & 5,373 \\
\hline 2013 & 6,590 \\
\hline
\end{tabular}

Fonte: FJP (2016)

Tabela 3 . evolução do PIB per capita

\begin{tabular}{|c|c|}
\hline Ano & PIB per capita (R\$) \\
\hline 2010 & $68.245,16$ \\
\hline 2011 & $104.568,53$ \\
\hline 2012 & $97.078,43$ \\
\hline 2013 & $114.347,9$ \\
\hline
\end{tabular}

Fonte: FJP (2016)

A dependência de Mariana em relação ao minério de ferro fica demonstrada na tabela 4, que apresenta a participação econômica por setor.

Tabela 4 . valor adicionado por setor

\begin{tabular}{|c|c|c|c|}
\hline Ano & $\begin{array}{c}\text { Agropecuária } \\
\text { (R\$ bi) }\end{array}$ & $\begin{array}{c}\text { Serviços } \\
\mathbf{( R \$} \text { bi) }\end{array}$ & $\begin{array}{c}\text { Indústria } \\
\text { (R\$ bi) }\end{array}$ \\
\hline 2010 & 0,010 & 0,971 & 2,588 \\
\hline 2011 & 0,010 & 1,401 & 4,193 \\
\hline 2012 & 0,012 & 1,465 & 3,753 \\
\hline 2013 & 0,019 & 1,776 & 4,635 \\
\hline
\end{tabular}

Fonte: FJP (2016)

Como resultado, conclui-se que $95 \%$ da arrecadação na localidade provém, direta ou indiretamente, da mineração, segundo dados da Secretaria de Estado de Fazenda de Minas Gerais. Tal arrecadação origina-se das atividades da Samarco e da Vale, principalmente (SDE, 2016).

Neste sentido, a Compensação Financeira pela Exploração Mineral - CFEM e o Imposto Sobre 
Serviços de Qualquer Natureza são majoritariamente oriundos da atividade mineral. Outros impostos como o ICMS, IPTU etc. também são importantes, devido às empresas terceirizadas que fornecem transporte, alimentação, projetos etc. às mineradoras. Na tabela 5 , são constatados os valores.

Tabela 5 . valores da CFEM e ISSQN

\begin{tabular}{|c|c|c|}
\hline Ano & CFEM (R\$) & ISSQN (R\$) \\
\hline 2013 & $89.598 .465,62$ & $23.910 .552,43$ \\
\hline 2014 & $71.556 .233,58$ & $25.901 .675,28$ \\
\hline 2015 & $61.562 .086,00$ & - \\
\hline
\end{tabular}

Fontes: DNPM (2016); Siconfi (2016)

A queda do valor obtido com a CFEM deve-se à redução do preço do minério de ferro no mercado internacional e os dados relativos ao ISSQN de 2015 estão indisponíveis no sistema do Tesouro Nacional. Tal dependência de Mariana em relação ao minério de ferro e sua extração fazem com que o município se encontre em uma encruzilhada a partir do rompimento da barragem ocorrida em 2015, pois a Samarco Mineração é a maior contribuinte individual da cidade. A paralisação de suas atividades resulta em significativa redução na arrecadação. Esta realidade é um dos aspectos controversos para se analisar na relação da cidade de Mariana com a mineração e no tocante ao rompimento da barragem de Fundão.

$\mathrm{Na}$ próxima seção, caracteriza-se a Samarco, demonstrando suas principais características e aspectos conexos que contribuem para uma descrição holística do fenômeno estudado.

\section{Caracterização da Samarco Mineração}

A Samarco Mineração é uma joint venture entre a Vale e a BHP Billiton, sendo a primeira maior produtora de minério de ferro do mundo e a segunda maior mineradora do mundo. A formação da empresa ocorreu no ano 2000, quando a Vale adquiriu uma participação de 63,06\% na Samitri (Sociedade Anônima Mineração da Trindade), por US\$ 525 milhões. A Samitri detinha, na época, $51 \%$ da Samarco Mineração e a BHP 49\%. Com a joint venture, cada sócio passou a deter 50\% (SEC, 2016).
Porém, o embrião da empresa surgiu em 1971, quando a Samitri (empresa da siderúrgica Belgo-Mineira) e a Marcona International (empresa norte americana) iniciaram as negociações para exploração do minério itabirítico (rocha com baixo teor de ferro), até então não explorado no país. A Samitri possuía as jazidas minerais e a Marcona possuía a tecnologia para processá-lo e produzir pelotas de minério de ferro (SEMAD, 2013b; SAMARCO 2007). Em 1973, criou-se a Samarco Mineração, com 51\% das ações para a Samitri e 49\% para a Marcona International. Em 1975, iniciaram-se as obras de construção e, em 1977, as atividades produtivas. Nesse mesmo ano, a Marcona é incorporada pela Utah International, formando a Utah-Marcona Corporation. Em 1984, a mineradora australiana BHP compra a Utah International (SAMARCO, 2007).

O principal produto da empresa são pelotas de minério de ferro. Deste modo, o teor de ferro eleva-se de $46 \%$ para $62 \%$. Para isso ocorrer, a Samarco possui três concentradores instalados na unidade de Germano, em Minas Gerais e quatro usinas de pelotização na unidade de Ubu, no município de Anchieta, ES, que beneficiam o minério e aumentam o seu teor de ferro. O produto é então estocado em pátios até seu embarque no porto. As duas unidades industriais são interligadas por três minerodutos, com quase 400 quilômetros de extensão cada, que transportam a polpa de minério de ferro entre os dois estados. Tais minerodutos atravessam 25 cidades nos dois estados (SAMARCO, 2014a).

A empresa extrai o minério na porção leste do Quadrilátero Ferrífero, em uma área chamada Complexo Alegria, na unidade de Germano (divisa entre Mariana e Ouro Preto), com reservas aproximadas de 3,3 bilhões de toneladas de minério de ferro. Tal extração é realizada a céu aberto, através de tratores, escavadeiras, carregadeiras e caminhões. Um sistema de correias transportadoras de longa distância leva o minério até a usina de beneficiamento, onde se dão as etapas de britagem e concentração (SAMARCO, 2008).

A Samarco possui ainda uma usina hidrelétrica, em Muniz Freire (ES), e participa do consórcio da usina hidrelétrica de Guilman-Amorim, em Antônio Dias e Nova Era (MG). Vende minério de ferro para 19 países, na Europa, nas Américas, na Ásia, na África e no Oriente Médio (SAMARCO, 2014).

A evolução dos resultados da Samarco consta na tabela 6 . 
Tabela 6 . evolução dos resultados da Samarco

\begin{tabular}{|c|c|c|c|c|c|}
\hline Ano & $\begin{array}{c}\text { Produção total } \\
\text { (milhões de ton.) }\end{array}$ & $\begin{array}{c}\text { Receita bruta } \\
\text { (R\$ bi) }\end{array}$ & $\begin{array}{c}\text { Lucro líquido } \\
\text { (R\$ bi) }\end{array}$ & $\begin{array}{c}\text { Ativos totais } \\
\text { (R\$ bi) }\end{array}$ & $\begin{array}{c}\text { Patrimônio líquido } \\
\text { (R\$ bi) }\end{array}$ \\
\hline 2010 & 23.329 & 6,324 & 2,247 & 5,542 & 1,377 \\
\hline 2011 & 22.437 & 7,117 & 2,914 & 7,095 & 1,807 \\
\hline 2012 & 22.066 & 6,611 & 2,646 & 11,001 & 3,274 \\
\hline 2013 & 21.737 & 7,240 & 2,731 & 15,032 & 3,758 \\
\hline 2014 & 25.075 & 7,601 & 2,806 & 19,557 & 4,313 \\
\hline
\end{tabular}

Fonte: SAMARCO (2014b, p.14)

Em relação aos funcionários, na tabela 7 é demonstrada sua evolução.

Tabela 7 . evolução do número de funcionários diretos e indiretos da Samarco

\begin{tabular}{|c|c|c|}
\hline Ano & Empregados próprios & Empregados terceirizados \\
\hline 2010 & 2.061 & 2.856 \\
\hline 2011 & 2.359 & 3.370 \\
\hline 2012 & 2.436 & 3.433 \\
\hline 2013 & 2.899 & 3.492 \\
\hline 2014 & 3.113 & 3.517 \\
\hline
\end{tabular}

Fonte: SAMARCO (2014b, p.80); SAMARCO (2010, p.61)

Com as tabelas 6 e 7, é possível verificar que a Samarco é uma empresa de grande porte, estando entre as 10 maiores exportadoras do Brasil. Com a conclusão das obras da Quarta Pelotização, em 2014, a Samarco amplia sua produção, que chega a 30,5 milhões de toneladas (SAMARCO,2014).

Devido às características peculiares da produção, a Samarco gera uma quantidade elevada de rejeitos (arenosos e lamas) no beneficiamento do minério de ferro, sendo tais rejeitos armazenados em três barragens - Germano, Fundão e Cava do Germano. A água advinda desse processo é tratada nas estações de tratamento de efluentes e armazenada na barragem de Santarém.

A evolução da produção de rejeito consta na tabela 8 .

Tabela 8 . evolução da produção de rejeitos

\begin{tabular}{|c|c|}
\hline Ano & $\begin{array}{c}\text { Rejeitos } \\
\text { (milhões de ton.) }\end{array}$ \\
\hline 2010 & 16,358 \\
\hline 2011 & 15,656 \\
\hline 2012 & 16,694 \\
\hline 2013 & 16,542 \\
\hline 2014 & 21,978 \\
\hline
\end{tabular}

Fonte: SAMARCO (2014b, p.56); SAMARCO (2012, p.56); SAMARCO (2013, p.74) 
Como é possível observar, em 2014 houve uma ampliação do volume de rejeitos produzidos, em função do aumento da produção. Todavia, as barragens estavam operando perto do limite. Desta maneira, a barragem de Fundão estava passando um processo de alteamento, isto é, a elevação do aterro de contenção. Segundo SEMAD (2013, p.2) trata-se de um projeto de unificação e alteamento das barragens de rejeito Germano e Fundão, para ampliação da capacidade de armazenamento. A elevação seria de 20 metros. Contudo, em 05 de novembro de 2015, a barragem de Fundão colapsou, resultando em um dos maiores desastres ambientais do Brasil, conforme demonstrado na próxima seção.

\section{Bento Rodrigues e o desastre: vivendo no abismo}

Bento Rodrigues carrega em sim toda uma história ligada à mineração. Fundada em fins do século 17, pelo bandeirante paulista de mesmo nome, foi um dos primeiros distritos auríferos das Minas Gerais e ponto de passagem para Ouro Preto e Diamantina (locais de extração de ouro e diamante no século 18).

Sobre sua origem, Vasconcellos (1904) observa

Uma légua pequena além dos Camargos, Bento Rodrigues, que de sua roça do Guaipacaré, perto de Guaratinguetá, havia subido com Artur de Sá, achou o ribeiro, a que deu seu nome, e de onde em cinco braças de extensão tirou cinco arrobas de ouro, caso que deu lugar à invasão dos flibusteiros em tal desordem, que desse arraial fizeram o mais barulhento lugar da antiguidade (VASCONCELOS, 1904, p.123).

O povoado é um subdistrito de Santa Rita Durão e contava com aproximadamente 600 pessoas, tendo como atividade econômica básica a indústria extrativa mineral, que empregava significativa parcela da mão de obra local. O comércio da localidade era pouco diversificado, registrando-se grande dependência da cidade de Mariana. Existiam bares, mercearias e restaurantes, com pouca relevância em termos de geração de renda (SEMAD, 2013b). O artesanato, turismo (ecológico, histórico e cultural) e atividades agrícolas também se faziam presentes, em caráter de subsistência principalmente. A distância até Mariana é de $35 \mathrm{~km}$.

Viana (2012) em sua tese de doutorado, abordando questões de sustentabilidade, elaborou um estudo em Bento Rodrigues. Na tabela 9 são apresentados dados relativos à dependência dos moradores em relação a atividade mineral.

Tabela 9 . relação com a mineração

\begin{tabular}{|l|c|}
\hline É empregado/subcontratado & $12 \%$ \\
\hline Tem familiar empregado/subcontratado & $14 \%$ \\
\hline É fornecedor & $2 \%$ \\
\hline Foi empregado/subcontratado & $44 \%$ \\
\hline Não tem relação & $28 \%$ \\
\hline
\end{tabular}

Fonte: Viana (2012, p. 203)

Como é possível observar, $72 \%$ mantinham, em algum momento, relação com as mineradoras do entorno (Vale e Samarco). Dos respondentes desta pesquisa, $14 \%$ residiam no local entre 10 e 20 anos, $60 \%$ entre 20 e 40 anos e $14 \%$ acima de 40 anos (VIANA, 2012, p. 204). Ou seja, eram habitantes tradicionais do lugar, com história de vida relacionada ao pertencer a uma comunidade. Histórias vindas do passado setecentista em alguns casos.

98\% dos pesquisados ganhavam até 5 salários mínimos, sendo $48 \%$ até 1 salário mínimo. Sobre a educação, $60 \%$ tinham o ensino fundamental incompleto, $24 \%$ o fundamental, $14 \%$ o médio e $2 \%$ analfabetos (VIANA, 2012, p. 205). Em outra pesquisa, compilando dados do IBGE, Wanderley (2015) observa que 84,3\% da população de Bento Rodrigues são de pretos e pardos (não brancos).

Todavia, a população local mantinha uma relação amistosa com a Samarco. 60\% dos entrevistados tinham uma visão positiva da mineração (VIANA, 2012, p. 206).

Em relação aos problemas da mineração, apresenta-se na tabela 10 os principais aspectos. 
Tabela 10 . problemas da mineração

\begin{tabular}{|c|c|c|c|c|}
\hline Poluição das águas & $\begin{array}{c}\text { Rompimento das } \\
\text { barragens }\end{array}$ & Poeira & $\begin{array}{c}\text { Alteração dos } \\
\text { costumes }\end{array}$ & $\begin{array}{c}\text { Possibilidade de } \\
\text { desapropriação }\end{array}$ \\
\hline $94 \%$ & $68 \%$ & $64 \%$ & $66 \%$ & $64 \%$ \\
\hline
\end{tabular}

Fonte: Viana (2012, p. 215)

De forma cabal, os moradores de Bento Rodrigues antiviram que a ameaça estava a poucos quilômetros de sua tradicional comunidade. 94\% citaram poluição das águas e 68\% rompimento das barragens como problemas. E foi o que ocorreu.

Conforme IBAMA (2015, p. 3), a barragem de Fundão continha 50 milhões de $\mathrm{m}^{3}$ de rejeitos de mineração de ferro, sendo que houve um vazamento de 34 milhões $\mathrm{de}^{3}$ desses rejeitos, que foram lançados no meio ambiente. Outros 16 milhões continuaram vazando. De início, a lama atingiu a barragem de Santarém (armazenadora de água), o que resultou em uma onda que percorreu $55 \mathrm{~km}$ no rio Gualaxo do Norte até desaguar no rio do Carmo. Outros $22 \mathrm{~km}$ foram percorridos até seu encontro com o rio Doce. Neste rio, a lama continuou até a foz no Oceano Atlântico, chegando ao município de Linhares (ES) no dia em 21 de novembro de 2015, totalizando 663,2 km de corpos hídricos diretamente impactados.

Como resultado do rompimento da barragem, resumidamente tem-se que:

- 19 pessoas morreram;

- o povoado de Bento Rodrigues foi destruído;

- diversas comunidades foram afetadas pela lama (Paracatu de Baixo, Paracatu de Cima, Águas Claras, Campinas, Borba, Pedras, Bica, Gesteira, além do centro urbano do município de Barra Longa - distante 70km)

- comunidade indígena (Krenak, em Resplendor - MG) afetada na pesca e outros usos tradicionais da água;

- mais de 600 refugiados - refugiar: retirar-se para lugar em que haja segurança, proteção, segundo Houaiss (2009, p.1633);

- impactos econômicos para Mariana e Ouro Preto (queda da arrecadação);

- desemprego;

- impacto ambiental incomensurável.

Bento Rodrigues está situada a uma altitude de 704m. A barragem de Fundão estava originalmente a 830m, depois foi para 920m (ampliação da altura em 90m, com nova expansão solicitada para 940m). Ou seja, mais $210 \mathrm{~m}$ de desnível, uma altura equivalente a 70 andares. A distância entre a barragem de Fundão e o povoado é de aproximadamente 5,5km. Já até a barragem de Santarém 2,5km. Nas figuras 1 e 2 demonstra-se o local. 
Figura 1. Impacto do rompimento

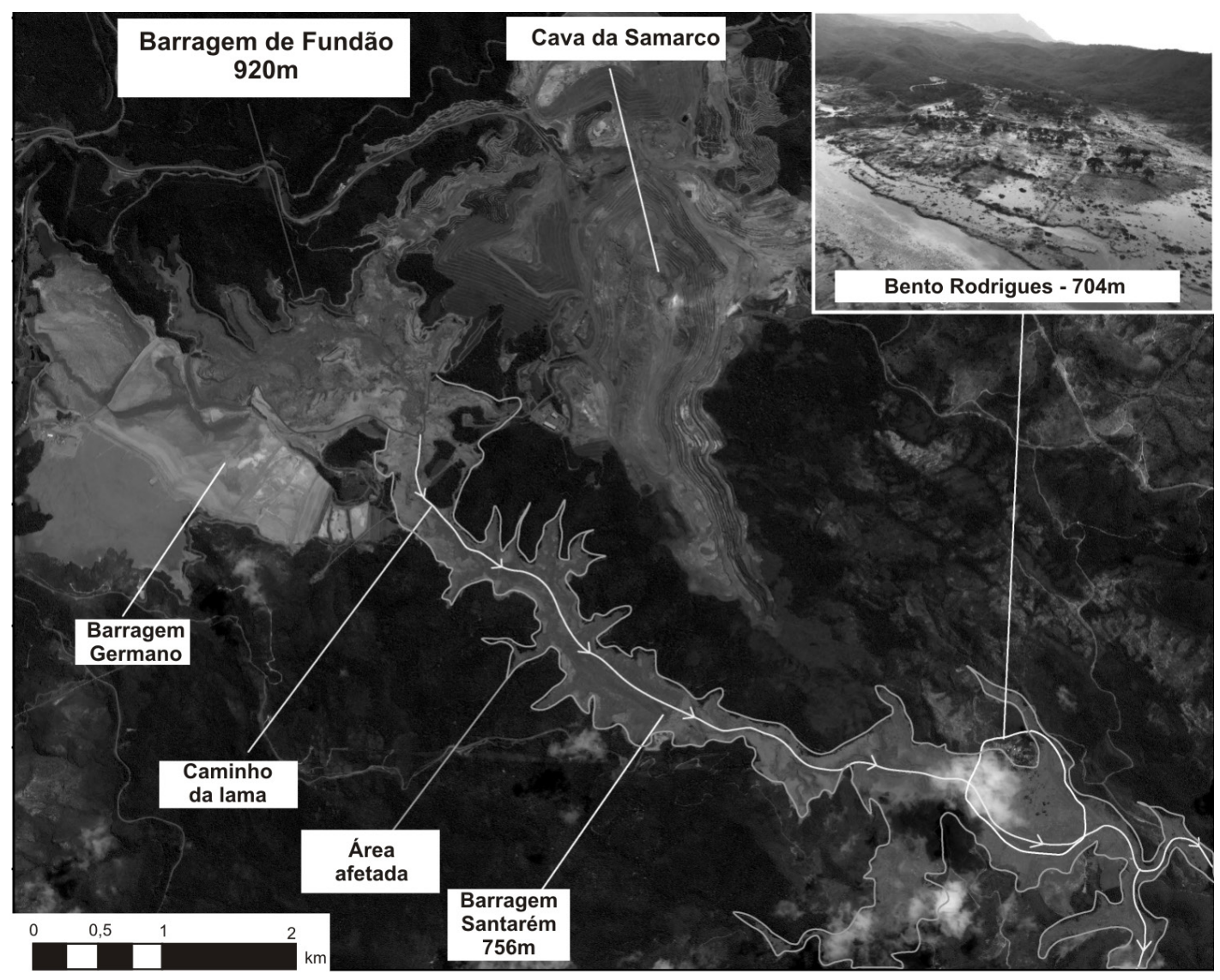

Fonte: adaptado de CNES (2015)

Figura 2 . Barragens da Samarco

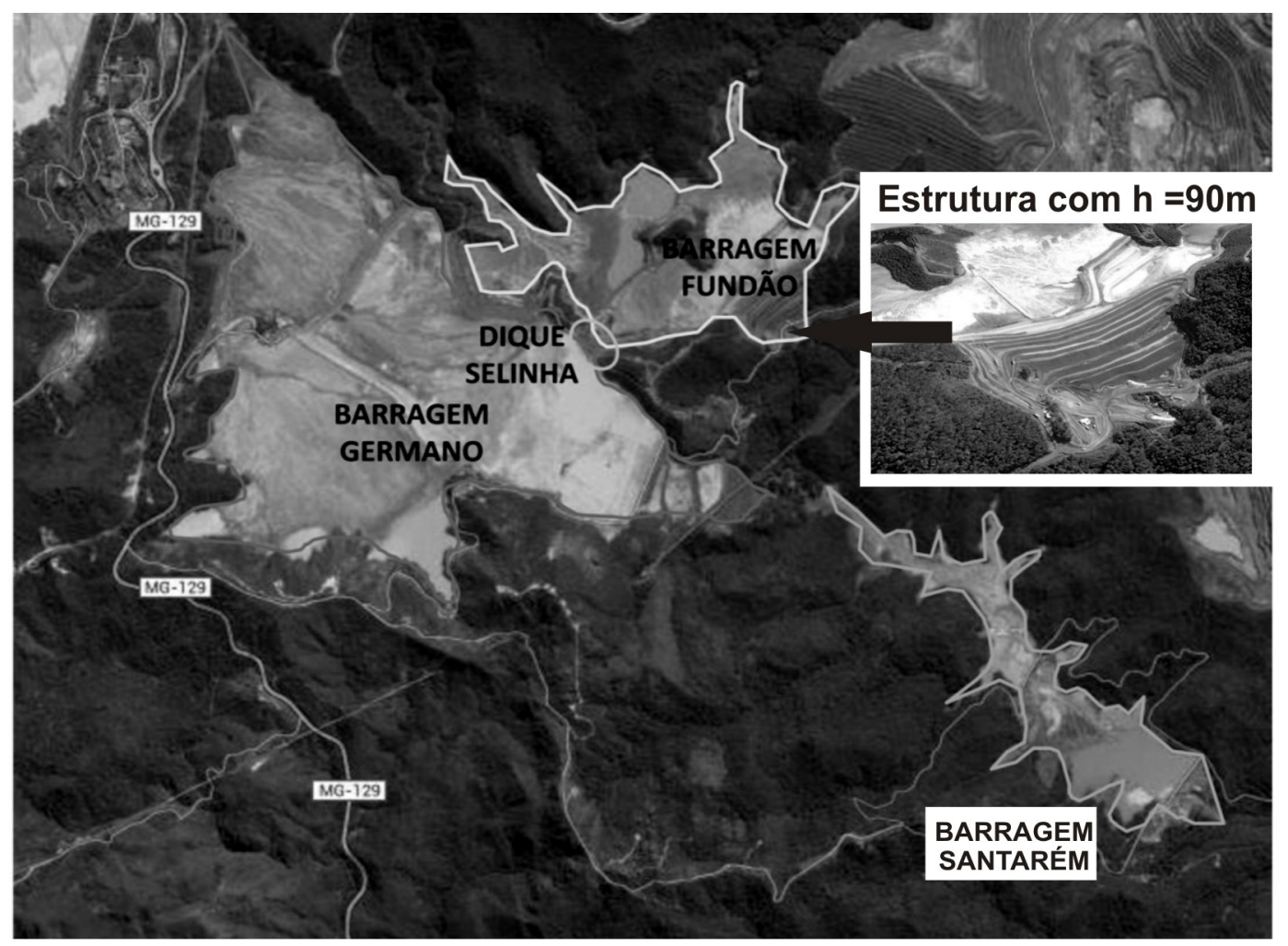

Fonte: adaptado de SAMARCO (2015); Google Earth (2015) 
No início de 2016, a União e os Governos de Minas Gerais e do Espírito Santo assinaram um acordo de indenização com a Samarco, a Vale e a BHP que determina a destinação de $\mathrm{R} \$ 20$ bilhões ao longo de quinze anos para a população atingida e a recuperação da bacia do rio Doce. Acordo contestado pelo Ministério Público e que foi suspenso pelo Superior Tribunal de Justiça (STJ).

Porém, os dados sobre o desastre estão sendo coletados, investigações estão em andamento, relatórios produzidos etc. Ainda não há clareza sobre as razões e consequências do evento. Não obstante, é possível buscar esclarecimentos sobre o entendimento de que os diretamente afetados tiveram sobre a tragédia, ou seja, as percepções das pessoas que estavam em Bento Rodrigues quando ocorreu o rompimento da barragem de Fundão.

Deste modo, no tópico a seguir apresenta-se os procedimentos metodológicos empregados para a coleta e análise dos dados acerca do fenômeno rompimento da barragem de Fundão pertencente a Mineradora Samarco e suas consequências para Bento Rodrigues.

\section{Procedimentos Metodológicos}

Para a realização desta investigação de cunho fenomenológico adotou-se uma série de procedimentos no tocante ao processo de coleta de dados, como o cuidado com o sujeito de pesquisa, deixando-o ciente dos objetivos da pesquisa e o caráter voluntário e confidencial da sua colaboração.

Concretamente, o rompimento da barragem da Samarco ocorreu em 05 de novembro de 2015, quinta-feira. Do dia 06 ao dia 10 de novembro foram realizadas 08 entrevistas com moradores de Bento Rodrigues, no ginásio em que ocorria o alojamento e em hotéis em que foram hospedados. Tal aspecto garante ao processo de coleta de dados à possibilidade de atingir o mais próximo da consciência do sujeito de investigação, pois o fenômeno estava ocorrendo, não havendo tempo para vieses advindos da proliferação de discursos construídos por mídia, agentes públicos, Samarco. Os sujeitos de pesquisa foram quatro mulheres e quatro homens, conforme características:

M01 - do lar. Marido desempregado.

M02 - do lar. Marido desempregado.
M03 - do lar. Separada, desempregada, filhos recebem pensão.

M04 - auxiliar de serviços gerais.

H01- pedreiro.

H02 - aposentado

H03 - lavrador

H04 - motorista de caminhão pesado.

As entrevistas foram gravadas e depois transcritas. Não houve um roteiro preestabelecido de perguntas, tratando-se de entrevistas não estruturadas. Todavia, essas foram efetuadas a partir de eixos norteadores:

- Samarco; barragem; vida pregressa; rompimento da barragem; família; emprego e renda; futuro; passado; comunidade e outros aspectos decorrentes dos primeiros.

Assegurou-se anonimato aos depoentes, só sendo entrevistadas aquelas pessoas que gostariam de falar e expressar suas observações. Foi esclarecido aos participantes se tratar de uma pesquisa de opinião (consulta verbal de caráter pontual, realizada por meio da metodologia fenomenológica, através da qual o participante foi convidado a expressar suas avaliações e sentidos que atribuíram ao desastre com a barragem). Ademais, todos os respondentes deram anuência, livres de simulação, fraude, erro ou intimidação de quaisquer espécies, após esclarecimento sobre a natureza da pesquisa (elaboração de artigo), sua justificativa, seus objetivos, métodos, potenciais benefícios para esclarecimento do fenômeno e riscos (possibilidade de danos à dimensão física, psíquica, moral, intelectual, social, cultural do colaborador, em qualquer etapa da pesquisa e dela decorrente).

Uma vez compreendido o processo de coleta de dados, necessário se faz esclarecer como foi realizada a análise dos mesmos a partir do método fenomenológico de investigação. Convém destacar que tal método parte de todos os fundamentos fenomenológicos descritos neste trabalho.

Logo, neste estudo, fez-se uso, além da fenomenologia, do método fenomenológico proposto por Sanders (1982). Enquanto método de captar e compreender a realidade, o emprego deste torna-se um caminho pertinente.

Masini (1989) observou que não existe um único método fenomenológico, mas sim uma atitude. Atitude 
esta de abertura do ser humano para apreender o que se mostra e ir além da aparência e pré-concepções.

Segundo Moreira (2002), em se tratando de processo de coleta de dados, o método de Sanders (1982) sugere que é importante que as palavras exatas dos entrevistados estejam registradas para uma melhor análise; além disso, é melhor utilizar poucas questões e aprofundá-las do que simplesmente assumir que um maior número de questões dará automaticamente maior volume de informação.

São três os componentes fundamentais do método de Sanders (1982):

1. Determinação dos limites de que e de quem deve ser investigado. Quanto ao que, tem-se o significado do rompimento da barragem para quem o vivenciou. No tocante ao quem investigar, trabalha-se em profundidade com 08 sujeitos;

2. Coleta de dados: ocorre através de entrevistas;

3. Análise fenomenológica dos dados: ocorre com base na observância dos seguintes procedimentos:

a) Descrição do fenômeno tal qual está apresentado nos relatos.

b) Identificação dos temas que emergem dos relatos. O que identifica um tema são sua importância e centralidade, e não a frequência com que aparece no discurso. Ressalta-se que a fenomenologia permite a identificação do dito pelo não dito, ou seja, há temas que podem ser inferidos pelo pesquisador.

c) Junção dos temas em unidades de sentido, que caracterizam a estrutura significativa do fenômeno.

Observa-se que a abordagem fenomenológica de Sanders (1982) contempla todo o processo de pesquisa e, não somente, a análise de dados. No mais, esta estrutura metodológica foi desenvolvida considerando a prática da redução fenomenológica em todo processo de interpretação visando extrair a essência dos fenômenos encoberta pela aparência.

A redução fenomenológica consiste, de fato, na parte fundamental de qualquer abordagem fenomenológica, pois conduz o pesquisador ao caminho para suspensão das pré-concepções na busca para se chegar às coisas mesmas.

A realização da redução fenomenológica busca diminuir ou acabar com o subjetivismo que poderia se tornar um empecilho no que diz respeito à confiabilidade deste trabalho.
São efetuadas duas reduções: a eidética e a fenomenológica (ou transcendental). Bochenski (1971, p. 51-58) afirma que a redução eidética deve ser efetuada da seguinte maneira, por parte do pesquisador:

Passos da Redução Eidética

1. Eliminação no grau possivel do subjetivo: assumir atitude objetiva frente ao dado. A volta às coisas mesmas exige não só a exclusão das atitudes subjetivas, mas também os de toda objetividade. Deve-se ver somente o que é dado, o fenômeno, e nada mais.

2. Exclusão do teórico: eliminação momentânea de todas as descobertas, hipóteses, teorias, ou outro conhecimento prévio. No curso da investigação fenomenológica não se pode fazer qualquer uso de métodos indiretos de conhecimento.

3. Suspensão da tradição: exclusão das tradições das ciências e das autoridades humanas. Somente as próprias coisas, como fenômenos que surgem diante dos olhos do pesquisador, devem ser observadas e nada mais.

4. Ver todo o dado, e não somente alguns aspectos do objeto: isto em si é uma clara e simples regra. Foi formulada de modo claro e aplicada conscientemente, pois o homem tem uma forte tendência para ver apenas determinados aspectos do objeto, em vez dos dados. Assim, a primeira tarefa da investigação fenomenológica é revelar os fenômenos negligenciados.

5. Descrever o objeto, analisando suas partes: isto significa que o fenômeno deve ser descrito e analisado, uma vez que cada fenômeno é infinitamente complexo. A visão geral é mais adequada para entender as relações mútuas entre os fenômenos.

O objetivo desta redução é atingir a essência, o eidos. Então, a realidade, em função da livre consideração de todas as possibilidades que a razão descobre, perde as características individuais e se revela uma essência constante e invariável.

Já a redução fenomenológica ou transcendental, busca limitar o conhecimento ao fenômeno da experiência de consciência. Para isso, procura desconsiderar o mundo real, em uma espécie de suspensão do juízo. Em outras palavras, o põe entre parênteses.

Deste fato, advém a escolha intencional do formato deste trabalho, procurando ser descritivo do fenômeno. Destaca-se que o fenomeno da fenomenologia trata daquilo que se oculta naquilo que se manifesta no 
fenômeno tomado em sentido vulgar (ou seja, o ente que se manifesta). Assim sendo, consiste no que está implícito, não tematizado, mas que pode ser levado à manifestação e deste modo mostra-se a partir dele mesmo. Não é o que se dá à experiência, mas que a constitui como fundamentação. Cabe à fenomenologia desvelar aquilo que por si está oculto (STEIN, 1966, p. 38-39).

Desse modo, uma vez apresentados os pressupostos fenomenológicos empregados para o processo de coleta e análise dos dados, tem-se a seguir a apresentação dos dados interpretados.

\section{Análise fenomenológica dos relatos dos moradores}

Apresentam-se as unidades de sentido identificadas com base na análise fenomenológica dos dados, a saber: a) Assistencialismo da Samarco; b) Moradia; c) Medo da barragem e da morte; d) Perdas e mudança radical; e) Momentos após o rompimento - dor e desespero; f) Pertencimento a uma comunidade família; Futuro.

Para exposição dos dados categorizados, apresentamse excertos das entrevistas transcritas.

\section{Unidade de sentido 1 - Assistencialismo da Samarco}

\begin{tabular}{|l|l|}
\hline Frases & Depoimento \\
\hline $\begin{array}{l}\text { “...] sei de uma caixa d’água lá que foi } \\
\text { colocada há pouco tempo porque sempre } \\
\text { faltava água lá pra nós". }\end{array}$ & M01 \\
\hline $\begin{array}{l}\text { “[...] eles estavam querendo fazer asfalto. } \\
\text { Estava começando a arrumar a água”. }\end{array}$ & M02 \\
\hline $\begin{array}{l}\text { "[...] recebia alguma verba, eu ouvia falar } \\
\text { que eles faziam doação pra escola, como } \\
\text { computador, cadeira nova, essas coisas. } \\
\text { Sempre ouvi dizer que a Samarco doava } \\
\text { essas coisas para a escola”. }\end{array}$ & M03 \\
\hline $\begin{array}{l}\text { "[...] estavam fazendo uma caixa d’água pra } \\
\text { gente lá, ela que tava pagando o serviço”. }\end{array}$ & H02 \\
\hline $\begin{array}{l}\text { “[...] estavam ajudando agora lá com a água, } \\
\text { porque tava muita falta de água lá. Tava até } \\
\text { fazendo uma coisa muito boa lá, doando } \\
\text { água tratada pra nós, só isso só”. }\end{array}$ & H04 \\
\hline
\end{tabular}

Nesta unidade de sentido, observa-se que a Samarco Mineração se fazia presente na comunidade de Bento Rodrigues, desenvolvendo ações pontuais para a melhoria do local, como a construção de caixa de água, doações para a escola ou projeto de asfalto. Ademais, a empresa também comprava ou intentava adquirir terrenos na localidade. H03 chegou a dizer: "Queria sair de lá, a gente queria que a Samarco indenizasse a gente pra poder sair né? Ai acomodou, acomodou, acomodou até que aconteceu essa tragédia".

Evidencia-se, portanto, a existência de um relacionamento da mineradora Samarco com a comunidade de Bento Rodrigues estabelecido anteriormente ao desastre ambiental.

\section{Unidade de sentido 2 - Moradia}

\begin{tabular}{|l|l|}
\hline Frases & Depoimento \\
\hline $\begin{array}{l}\text { "[...] cuidado tem barragem aí pra cima, } \\
\text { esse trem arrebenta }[. . .] \text { porque a gente } \\
\text { morando dentro de um abismo, né”? }\end{array}$ & $\mathrm{H}$ e2 \\
\hline $\begin{array}{l}\text { "[...] todo mundo reunia e falava que tinha } \\
\text { perigo, mas ninguém acreditava, falava que } \\
\text { tava normal, que era inspecionada, mas nós } \\
\text { sempre falava: tira nós do Bento". }\end{array}$ & $\mathrm{H} 03$ \\
\hline $\begin{array}{l}\text { "Imagina uma barragem daquele tamanho } \\
\text { em cima do lugar que você mora. A gente } \\
\text { morava num abismo, né? Mas a gente não } \\
\text { construiu casa na área de risco, eles que } \\
\text { construíram a barragem onde a gente já } \\
\text { estava e acabou com tudo". }\end{array}$ & H04 \\
\hline
\end{tabular}

Observa-se nesta unidade de sentido a questão do habitar. Os moradores temem por sua segurança, reconhecem o perigo de estarem no que chamam de abismo, mas ações não são tomadas para evitar a catástrofe. Bento Rodrigues existia há mais de 300 anos e a Samarco há menos de 40 anos. O elemento confirmador da autenticidade e singularidade de ser de Bento Rodrigues está no morar no lugar, no pertencer a uma comunidade única.

A consciência da existência de um perigo à moradia em Bento Rodrigues existia, todavia, a intensidade da mesma não foi capaz de resultar em ações preventivas ao desastre.

\section{Unidade de sentido 3 - Medo da barragem e da morte}

\begin{tabular}{|l|l|}
\hline Frases & Depoimento \\
\hline $\begin{array}{l}\text { "A gente sempre soube sim, e sempre tinha } \\
\text { muito medo". }\end{array}$ & M01 \\
\hline “[...] todos lá sempre tiveram medo. Uma & M02 \\
vez eles falaram que ia estourar, todo \\
mundo saiu correndo e não estourou. & \\
Estava realmente correndo risco, mas eles & \\
não avisaram a gente, não informaram”. & \\
\hline
\end{tabular}




\begin{tabular}{|l|l|l}
\hline “[...] todo mundo estava tentando se salvar. & M04 \\
E naquele momento passou um saveiro & \\
e falou assim: corre gente, 'sobe aí, é o & \\
fim do mundo, nós vamos morrer todo & \\
mundo'. Aí a caminhonete levou a gente & \\
até o alto da igreja, até a caixa d'água, aí & \\
você via gente carregando os mais velhos & \\
nas costas, pessoas carregando pessoas no & \\
carrinho de mão, e foi um desespero total. & \\
A sensação era de que tava acabando tudo & \\
mesmo". & H02 \\
\hline "Todos tinham medo". & \\
\hline
\end{tabular}

O medo era uma constante em Bento Rodrigues. Medo de rompimento da barragem. Destaca-se a falta de aviso sobre o acontecido, o elemento surpresa que traz em si a questão da falta de informação, dos boatos e do imponderável. Outro aspecto importante é a questão da desesperança. Enquanto o acontecimento se processa, o fim parece inevitável, mas a vontade de se salvar impulsiona o agir, na busca de superação dos limites.

Nota-se que a comunidade indica que não houve aviso sobre o rompimento da barragem. Neste quesito, o elemento surpresa, ainda que se temesse o rompimento da barragem, causou impactos ainda maiores, pois não houve tempo.

\section{Unidade de sentido 4 - Perdas e mudança radical}

\begin{tabular}{|c|c|}
\hline Frases & Depoimento \\
\hline $\begin{array}{l}\text { "Mudou tudo, perdemos tudo, não sobrou } \\
\text { nada. Minha casa foi totalmente tomada } \\
\text { pela lama, perdemos tudo, só deu tempo } \\
\text { de sair com a roupa do corpo e pegar as } \\
\text { minhas filhas e sair correndo". }\end{array}$ & M01 \\
\hline $\begin{array}{l}\text { "Acabou tudo, a gente tinha dinheiro } \\
\text { guardado, acabou tudo. E meu marido } \\
\text { é desempregado. Tipo assim não tinha } \\
\text { serviço, as coisas que a gente conquistou } \\
\text { foi tudo embora na lama". }\end{array}$ & M02 \\
\hline $\begin{array}{l}\text { "[...] eu não tenho nem noção, porque tudo } \\
\text { que eu tinha foi embora na lama. Eu tenho } \\
\text { meu emprego, né? Que não sei onde vou } \\
\text { continuar, porque não existe mais a escola. } \\
\text { Não sei o que vai ser de mim e das minhas } \\
\text { filhas agora". }\end{array}$ & M04 \\
\hline $\begin{array}{l}\text { "[...] graças a Deus eu não perdi a minha } \\
\text { família, mas o resto eu perdi tudo, tudo que } \\
\text { eu tinha. Minha casa, tudo que eu e minha } \\
\text { família tinha a gente perdeu. A gente morava } \\
\text { todo mundo perto, inclusive eu morava de } \\
\text { aluguel, eu estava construindo minha casa, } \\
\text { quase acabando, o sonho da minha casa } \\
\text { própria acabou, foi tudo embora". }\end{array}$ & H01 \\
\hline
\end{tabular}

“[...] a gente só quer o que a gente tinha. Nossa casa pra morar todo mundo de novo, as criação que a gente tinha, né? Mas por enquanto a gente não sabe de nada que pode acontecer. Vamos ir ficando por aí até eles resolverem".

"Uai agora mudou tudo, eu tô ruim. Meu psicólogo ficou ruim, minha mente fica lá, ruim, entendeu? Tudo que aconteceu comigo e com minha família, com todos, né? Só fica esse desastre na vida da gente. Tragédia, eu perdi tudo, tudo. Minhas criação foi tudo embora, tudo embora pra água abaixo. Nosso futuro agora só Deus sabe, porque agora nós estamos na mão da Samarco. Eu saí com a roupa do corpo, perdi tudo. Casa, criação, eu tinha carro, tinha moto, tudo que você imaginar na vida eu perdi".

“[...] mudou tudo, perdemos tudo uai. Tá na coisa que não é da gente, tamo aqui de favor, perdemos tudo, casa, carro, documentação, dinheiro, perdemos tudo".

O rompimento acarreta como consequência, perdas e mudanças significativas, tanto materiais como emocionais. Desde a relação com seus animais (criação) até o sonho da casa própria. O orgulho também é impactado, pois o "estar de favor" significa fracasso. Em relação ao trabalho, não adianta ter, pois o local de trabalho (escola) não existe mais.

A perda é tamanha que a vida acabou. A vida de outrora, a vida bucólica de um lugarejo histórico, um modo de ser. Isso ficou claro nos dias seguintes ao acontecido, quando mais de seiscentas pessoas ocuparam os hotéis em Mariana. O que se via era tais pessoas sentadas nas calçadas diante dos hotéis conversando, reunidas em pequenos grupos tentando em vão reproduzir suas vidas pré-barragem. Grupos esses que não perambulavam pela cidade, mas buscavam ater-se ao ser de Bento Rodrigues, pois Mariana era um não-lugar, um ponto de passagem para o futuro desconhecido, já que o passado fora destruído.

Enfim, é como o verso de Carlos Drummond de Andrade: "E agora, José? A festa acabou, a luz apagou, o povo sumiu, a noite esfriou [...] Com a chave na mão quer abrir a porta, não existe porta [...] Sozinho no escuro qual bicho-domato, sem parede nua para se encostar, sem cavalo preto que fuja a galope, você marcha, José! José, para onde"?

Essa é a pergunta que se fazem: para onde irão? Se tudo acabou, só resta a mudança para o desconhecido, 
a incerteza, o devir. Há a necessidade de movimentarse, de seguir em frente, de reconstruir, de se reencontrar, mas muita dificuldade em delinear como tais necessidades poderiam ser processadas em ações factuais.

\section{Unidade de sentido 5 - Momentos após 0 rompimento - dor e desespero}

\begin{tabular}{|c|c|}
\hline Frases & Depoimento \\
\hline $\begin{array}{l}\text { "Sorte que tinha um caminhão pegando a } \\
\text { gente, esse caminhão salvou muita gente. } \\
\text { Crianças, idosos, gente de mais, e a gente } \\
\text { olhava e as casas já estavam caindo, água } \\
\text { chegando, vendo criança pedindo socorro, } \\
\text { pai com menino no colo que não conseguiu } \\
\text { sair e o menino morreu. Foi muito triste". }\end{array}$ & M02 \\
\hline $\begin{array}{l}\text { "Estava trabalhando na escola [...] quando } \\
\text { eu ouvi um barulho muito forte, aí pensei } \\
\text { 'deve ter acontecido alguma coisa'. Aí o } \\
\text { tempo escureceu e continue lá trabalhando, } \\
\text { normal. Quando de repente eu ouvi } \\
\text { todo mundo correndo, e gritando assim } \\
\text { 'corre que a barragem estourou'. Naquele } \\
\text { momento eu sai correndo, saí na rua, e } \\
\text { pedi um moço que estava passando que } \\
\text { pelo amor de Deus era para ele salvar as } \\
\text { minhas filhas. Naquele momento eu não } \\
\text { tinha noção de onde elas estavam, e onde } \\
\text { elas estavam já estava tudo inundado, lá já } \\
\text { não existia mais [...] Aí eu peguei minha } \\
\text { sobrinha pela mão, tentei entrar no ônibus } \\
\text { não consegui, porque já estava muito cheio, } \\
\text { todo mundo estava tentando se salvar [...] } \\
\text { quando cheguei lá no alto, junto com todo } \\
\text { mundo que tinha conseguido correr, a } \\
\text { gente viu a água passando assim com aquela } \\
\text { força e levando tudo. Aí a gente via ônibus, } \\
\text { via carro, aí sem saber se todo mundo tava } \\
\text { bem, se todo mundo tava vivo, e assim a } \\
\text { gente ficou e eu muito desesperada porque } \\
\text { eles falaram [...] que minhas filhas tinham } \\
\text { morrido e eu fiquei desesperada. Aí eu } \\
\text { consegui com um pessoal lá, abri uma } \\
\text { trilha no mato e consegui passar nessa } \\
\text { trilha, atravessei a lama, e consegui chegar } \\
\text { na estrada, quando eu cheguei na estrada eu } \\
\text { pedi uma carona para o moço e fui para lá } \\
\text { em Santa Rita, quando eu cheguei lá eu vi } \\
\text { minhas filhas". }\end{array}$ & M04 \\
\hline $\begin{array}{l}\text { "Quando aconteceu lá não deu tempo de } \\
\text { salvar nada, só saiu nós correndo da casa. } \\
\text { Graças a Deus minha família toda saiu. } \\
\text { Teve algum aviso? Não a gente só viu } \\
\text { aquele poeirão subindo, aquele barulho e o } \\
\text { pessoal da minha rua gritando: corre que a } \\
\text { barragem estourou". }\end{array}$ & H02 \\
\hline
\end{tabular}

"Quase que eu fui o desaparecido. Eu fiquei preso na lama lá por uns 40 minutos. Porque não deu pra eu sair com o carro mais, a lama tava levando tudo. Eu boiei na lama até conseguir segurar na beirada lá onde tinha mato e sai fora e salvei minha vida. Tô aqui por milagre de Deus. Lá em Bento não tem ninguém que passou mais risco que eu não, os que passaram tão sumido ou morto. Os que passaram não tão aqui pra contar história não".

Nesta unidade de sentido, observam-se momentos de agonia, choque e tristeza. Os relatos demonstram a falta de ação inicial das pessoas seguida de momentos de valentia e coragem. Isso é revelador dos momentos de superação física e psicológica que os moradores tiveram. Desde abrir trilha no mato até sair da lama com rejeitos, passando por caminhar dentre a destruição.

Idosos, crianças, animais de estimação, enfim, todos que puderam saíram correndo. Destacam-se ainda os sujeitos anônimos que usaram os meios disponíveis (furgões, caminhões, ônibus etc.) para prestar auxílio. Vários deles fizeram mais de um resgate. Outro ponto a se destacar é a não ação da Samarco, que não estava lá para socorrer as pessoas.

As atitudes de regaste e socorro aos afetados pela lama de rejeitos foram provenientes de pessoas físicas e, posteriormente, órgãos de resgate da cidade de Mariana.

Questionamentos são despertados em termos de um plano que a Samarco deveria ter e executar na hipótese de um rompimento da barragem, bem como, um conhecimento por parte da mineradora da trajetória da lama vazada. Tal conhecimento poderia ter resultado em um aviso para as demais localidades afetadas

O desespero tomou conta das pessoas, juntamente com o temor pela própria vida e dos entes queridos. Lama, ondas de rejeito, poeira e barulho contribuíam para o clima de hecatombe.

\section{Unidade de sentido 6 - Pertencimento a uma comunidade - familia}

\begin{tabular}{|l|l|}
\hline Frases & Depoimento \\
\hline $\begin{array}{l}\text { "Sempre fui moradora de Bento Rodrigues, } \\
\text { nasci lá e toda minha família é de lá". }\end{array}$ & M01 \\
\hline "Minha família toda é de Bento". & M02 \\
\hline
\end{tabular}




\begin{tabular}{|l|l|}
\hline $\begin{array}{l}\text { "Fiquei fora um tempo, mas nasci lá e } \\
\text { depois voltei. Minha família é toda de lá, } \\
\text { meus irmãos, minha mãe. Inclusive moro } \\
\text { com minha mãe e meus filhos". }\end{array}$ & M \\
\hline $\begin{array}{l}\text { "Sou de Bento, nascido e criado em bento } \\
\text { rodrigues. Minha família toda de lá". }\end{array}$ & H01 \\
\hline $\begin{array}{l}\text { "[...] minha família toda de lá. Na minha } \\
\text { casa são 9 pessoas, os filhos, os netos } \\
\text { moram tudo comigo". }\end{array}$ & H02 \\
\hline $\begin{array}{l}\text { "Nasci e cresci lá, meu pai é de lá, minha } \\
\text { família toda é do Bento". }\end{array}$ & H03 \\
\hline $\begin{array}{l}\text { "Há } 39 \text { anos, nasci lá. Tenho família lá, não } \\
\text { tenho esposa e filhos não, mas, meus pais } \\
\text { moram lá". }\end{array}$ & H04 \\
\hline
\end{tabular}

Ser de Bento Rodrigues é parte integrante do ethos dos depoentes. Representa não apenas o local de nascimento e moradia, mas o núcleo existencial das pessoas. É o local de vivências significativas, uma parte integrante dos seres, como se fosse constituinte dos corpos e consciências. São gerações de "Bentos", descendentes, em muitos casos, dos primeiros habitantes do lugar. São famílias com filhos, netos, genros, pais, mães, avós etc. que faziam daquele espaço um lugar com características específicas. Não era um povoado sem memória ou lugar dormitório, mas uma comunidade, onde as pessoas compartilhavam vivências significativas e intersubjetivas. $O$ povoado de Bento Rodrigues apresentava 300 anos de tradição, famílias, vivências, histórias, percepções, que não são facilmente reconstruídas.

\section{Unidade de sentido 7 - Futuro}

\begin{tabular}{|l|l|}
\hline Frases & Depoimento \\
\hline $\begin{array}{l}\text { "Nem imagino, tá? Porque eu moro lá } \\
\text { desde sempre, não sei nem o que fazer da } \\
\text { minha vida agora". }\end{array}$ & M01 \\
\hline $\begin{array}{l}\text { "[...] não sei como vai ser daqui para frente, } \\
\text { não sei para onde a gente vai, o que vai ser } \\
\text { da gente, a gente não tem mais nada". }\end{array}$ & M02 \\
\hline $\begin{array}{l}\text { "Estamos morando no hotel e isso é tudo } \\
\text { que eu sei [...] não tenho nem noção, porque } \\
\text { tudo que eu tinha foi embora na lama". }\end{array}$ & M04 \\
\hline $\begin{array}{l}\text { "A única coisa que consigo ver é que a } \\
\text { gente tá ferrado". }\end{array}$ & H01 \\
\hline $\begin{array}{l}\text { "Nós estamos na expectativa, todo mundo } \\
\text { tá esperando". }\end{array}$ & H03 \\
\hline
\end{tabular}

O futuro deixou de ser alçada das especulações advindas de devaneios por uma vida melhor e virou nebuloso, sombrio. A vida de então dos depoentes lhes foi tirada à força, sendo que foram entregues ao acaso. Para eles, tudo foi embora com a lama: vidas, bens e sonhos. Naquele momento o sonho acabou, restando apenas um quarto de hotel, com roupas e demais bens doados por desconhecidos. Muitos não tinham documentos, sendo refugiados em uma cidade estranha (pois Mariana era apenas a sede administrativa, lugar em que faziam compras ou resolviam questões bancárias, por exemplo). Vários depoentes afirmaram não saber nada sobre Mariana, não possuindo sequer conhecidos no lugar.

O futuro, então, converte-se apenas em saudades e nostalgia do passado.

\section{Sintese das unidades de sentido}

Cada sujeito pesquisado vivenciou o fenômeno de um modo específico. Desde aquele que o viveu en passant (estava em um lugar seguro e viu a destruição passar) até aquele que ficou 40 minutos preso na lama e quase morreu. Tem-se ainda, aquele que viu a morte de uma criança em cima da caçamba de um caminhão enquanto fugia.

Outros viram seus animais domésticos, cavalos, porcos, galinhas, plantações etc. sendo mortos e destruídos, ou ainda há aqueles que viram suas casas, carros, economias serem levados pela lama.

Contudo, todos eles relatam momentos de medo com a onda descendo a encosta, a poeira e o barulho advindos dessa descida. O temor de saber onde estava um ente querido, a preocupação com as crianças da escola, o desespero de saber que nada mais seria como antes. Nos relatos, é possível verificar que o pós-desastre acarretou mudança do ser-de-BentoRodrigues, pois não existe mais Bento Rodrigues. Agora são um tipo de gente expatriada, perdida no mundo, que terá que ir para um novo lugar, a chamada nova Bento (cujo terreno já foi escolhido).

Bento está morto, amigos estão mortos, tudo acabou. Esta é a síntese dos relatos. Para os depoentes, naquele momento, a esperança era apenas uma palavra sem significado.

Pontua-se, novamente, o momento de coleta dos dados apresentados e analisados neste trabalho: dias após o acontecimento do rompimento. Com isso, evidenciouse a essência dos pensamentos e percepções atrelados à vivência deste fenômeno ligado ao rompimento da barragem da Samarco. O objetivo foi a descrição e não o apontamento das causas e desdobramentos do desastre. 
Destaca-se, por fim, para estudos vindouros, que nestas unidades de sentido não se observa revolta imediata contra a mineração ou sua prática, tão somente pela sua falta de apoio às vítimas.

\section{Considerações finais}

$\mathrm{Na}$ parte introdutória deste trabalho se propôs atribuir vOz ao sujeito que vivenciou o fenômeno rompimento da barragem de Fundão pertencente à Mineradora Samarco atuante em Mariana-MG e suas consequências para Bento Rodrigues. E, a partir de um estudo fenomenológico, foi possível desvelar que tais sujeitos de pesquisa apresentavam uma relação com a Mineradora Samarco anterior ao rompimento fundamentada no assistencialismo por suas politicas de responsabilidade social, além da questão dos empregos gerados pela Mineradora. Observa-se ainda que em Bento Rodrigues os moradores possuíam medo do rompimento da barragem, mas julgavam que isso era pouco provável acontecer e que seriam devidamente avisados caso isso ocorresse. No mais, tinham consciência que moravam em um abismo, como disse uma moradora.

Os relatos desvelaram ainda a consciência do fim de uma vida e história construída por famílias na localidade de Bento Rodrigues, o foco era na perda, na percepção do fim, na dor e luta pela sobrevivência. Todavia, simultaneamente, observam-se elementos que indicam que mesmo havendo uma mudança radical na sua existência, há um futuro para quem sobreviveu a lama. Tem-se, então, que em um primeiro momento, os sujeitos de pesquisa não estavam revoltados, buscando culpados, mas sentindo as perdas e preparando-se para uma mudança, para a construção de um futuro de reparação e justiça. Os momentos imediatamente posteriores ao fim de Bento Rodrigues foram de reflexão, consciência de fim e continuidade, misto de tristeza pela extensão de perdas e agradecimento por se estar vivo. Em um momento como este, o presente é de fato o fim de todo um passado apagado pela lama e a possibilidade de um futuro reconstruído a partir do zero.

Logo, tem-se que escrever sobre um desastre de tal magnitude é deveras complexo. Deve-se buscar aterse apenas ao fenômeno, deixar que ele fale por si, já que este se encontra preso na ideologia e no sistema de produção e reprodução do capital existente. Quando das entrevistas, nos dias seguintes ao rompimento, o que se via era pessoas chorando, olhares perdidos, crianças assustadas, políticos preocupados em capitalizar, repórteres buscando notícias, bombeiros exauridos etc. Nesta investigação, buscou-se não a estrutura, mas a pessoa. Não importa aqui buscar culpados (para isso haverá a 'justiça'). Foi-se atrás de quem estava lá e vivenciou o acontecido, para que suas histórias fossem conhecidas e não se esquecesse de que um dia existiu Bento Rodrigues. As vítimas que morreram, a cidade de Mariana que depende economicamente da mineração, os 6.000 funcionários (entre próprios e terceirizados) da Samarco etc. todos perderam. A lama da barragem foi destruindo tudo em seu caminho até o oceano.

Dito isto, cumpre esclarecer que não há uma conclusão, pois os fatos estão se sucedendo. Qualquer análise substantiva neste momento será mais do campo preditivo que factual. Não obstante, o apresentado possui elementos que cumprem o proposto: analisar as vivências significativas daqueles que estavam lá.

No Brasil não é comum desastre dessa proporção. Povoados como Bento Rodrigues serem vítimas de tal desastre também não. Cidades como Mariana menos ainda. $\mathrm{O}$ mesmo se pode dizer de uma empresa como a Samarco, que outrora era premiada e elogiada por muitos. Em suma, existem muitas variáveis que são de difícil apreensão, exigindo cautelosa análise de todas elas, para que se possa fazer uma adequada interpretação.

Neste trabalho, em caráter inicial, apenas levantouse um debate, que necessita ser discutido através de dissertações, teses, livros e documentários. Ou seja, em sua leitura mister se faz entender que ele foi produzido em um espaço-tempo muito peculiar. $\mathrm{O}$ espaço: Mariana e Ouro Preto, com toda sua carga histórico-cultural. O tempo: pré,durante e-pósdesastre. Isso porque se poderiam fazer análises com os olhos e mentes de alguém recém-chegado, que não conhece o habitus e o ethos do lugar e de sua gente. Tais análises, se não fossem rigorosas em termos epistemológicos, axiológicos e ontológicos, seriam apenas discursos enviesados, buscando respostas para perguntas que não foram efetuadas.

Tão pouco neste estudo há respostas. Talvez algumas indagações e provocações. Ou no máximo explicitação de inquietudes. Não de quem escreve, mas de quem falou (os depoentes). Hoje, se os sujeitos da pesquisa fossem entrevistados, provavelmente falariam outras coisas. Não se lembrariam dos detalhes, a 
Samarco já indicou o terreno para a nova Bento, já receberam auxílios, suas vidas foram (e estão sendo) reconstruídas etc. Ou seja, são novas pessoas, que estão recomeçando a vida em uma nova terra. Estão deixando para trás tudo (foram levadas a deixar).

Portanto, o que concretamente existe, é aquilo que foi dito e as consequências do rompimento. O que foi dito, pelos depoentes, está sintetizado nas páginas precedentes. As consequências ainda durarão décadas. Mas, sucintamente, pode-se dizer que o que ocorreu foi o extermínio de um modo de ser de um povoado e sua gente, foi a aniquilação da história e da cultura. Por acaso, sorte ou outro nome que as pessoas costumam usar, o desastre ocorreu durante o dia. Caso fosse a noite, devido à singularidade do povoado, seriam centenas de mortos.

Por fim, observa-se que o fim de Bento Rodrigues significou o aparecimento de uma nova realidade, que dissolveu e transformou tudo e todos. Mas o que será de seus antigos moradores, só o tempo dirá.

\section{Referências bibliográficas}

BOAVA, F.M.F.M.; O tipo ideal de estratégia: um estudo fenomenológico social em arranjo produtivo local moveleiro. 2012. 290 p. Tese (Doutorado em Administração) - Universidade Federal de Lavras, Lavras, 2012.

BOCHENSKI, J.M. Los metodos actuales del pensamiento. Madrid: Rialp, 1971.

CHAUÍ, M. Convite à filosofia. Ática: São Paulo, 2005.

CNES. Areas affected by Samarco dam collapses at Bento Rodrigues, Mariana City, in Minas Gerais State, Brazil, 2015. Disponível em https://www. disasterscharter.org/image/journal/article.jpg?img_ $\mathrm{id}=226786 \& \mathrm{t}=1448015017028$ Acesso em $07 \mathrm{fev}$ 2017.

DNPM. Distribuição CFEM. Disponível em https://sistemas.dnpm.gov.br/arrecadacao/extra/ Relatorios/distribuicao_cfem.aspx Acesso em $07 \mathrm{fev}$ 2017.

FJP. PIB de Minas Gerais: anexo estatístico 20101013 Disponível em http://www.fjp.mg.gov.br/ index.php/produtos-e-servicos1/2745-produtointerno-bruto-de-minas-gerais-pib-2. Acesso em 07 fev 2017.

GIORGI, A. Difficulties encountered in the application of the phenomenological method in social sciences. Análise psicológica, vol. XXIV, no.3, p. 353-361, 2006.

GOOGLE EARTH. Disponível em https://www. google.com/earth/. Acesso em 07 nov 2015.

HOUAISS, A. Dicionário Houaiss da língua portuguesa. Rio de Janeiro: Objetiva, 2009.

HUSSERL, E. Ideias para uma fenomenologia pura e para uma filosofia fenomenológica: introdução geral à fenomenologia pura. Aparecida: Ideias \& Letras, 2006.

HUSSERL, E. Investigações lógicas: sexta investigação (elementos de uma elucidação fenomenológica do conhecimento). São Paulo: Nova Cultural, 1988.

IBAMA. Laudo técnico preliminar: impactos ambientais decorrentes do desastre envolvendo o rompimento da barragem de Fundão, em Mariana, Minas Gerais. Brasília, 2015.

IBGE. Informações completas Mariana. Disponível em http://cod.ibge.gov.br/9AQ Acesso em 07 fev 2017.

MASINI, E. F.S. Enfoque fenomenológico de pesquisa em educação, In: FAZENDA, I. Metodologia da pesquisa educacional. São Paulo: Cortez, 1989.

MOREIRA, D. A. O método fenomenológico na Pesquisa. São Paulo: Pioneira, 2002.

SAMARCO MINERAÇÃO. Mapa das barragens, 2015. Disponível em http:// www.samarco. com/2015/11/17/mapa-das-barragens/ Acesso em 07 fev 2017.

SAMARCO MINERAÇÃO. Relatório anual de sustentabilidade, 2007.

SAMARCO MINERAÇÃO. Relatório anual de sustentabilidade, 2008.

SAMARCO MINERAÇÃO. Relatório anual de sustentabilidade, 2010.

SAMARCO MINERAÇÃO. Relatório anual de sustentabilidade, 2012.

SAMARCO MINERAÇÃO. Relatório anual de sustentabilidade, 2013. 
SAMARCO MINERAÇÃO. Relatório anual de sustentabilidade, 2014a.

SAMARCO MINERAÇÃO. Relatório da administração e demonstrações financeiras, 2014b.

SANDERS, P. Phenomenology: a new way of viewing organizational research. Academy of Management Review, vol. 7, no. 3, p. 353-360, 1982.

SDE. Relatório: avaliação dos efeitos e desdobramentos do rompimento da barragem de Fundão em Mariana-MG. Belo Horizonte, 2016.

SEC. BHP and CVRD enter agreement to rationalise the Alegria Iron Ore Complex in Brazil, 2000. Disponível em https:// www.sec.gov/Archives/edgar/containers/ fix031/811809/000081180900000111/000081180900-000111-0001.txt Acesso em 07 fev 2017.

SEMAD. Parecer único $\mathrm{n}^{\mathbf{0}} 262 / 2013$. Belo Horizonte, 2013a.

SEMAD. Parecer único PA COPAM: 00015/1984/100/2013. Belo Horizonte, 2013b.

SINCOFI. Sistema de informações contábeis e fiscais do setor público brasileiro. Disponível em https://siconfi.tesouro.gov.br/siconfi/pages/public/ consulta_finbra/finbra_list.jsf Acesso em $07 \mathrm{fev}$ 2017.

STEIN, E. Introdução ao pensamento de Martin Heidegger. Porto Alegre: Ithaca, 1966.

VASCONCELLOS, D. Historia antiga das Minas Geraes. Bello Horizonte: Imprensa Official do Estado de Minas Geraes, 1904.

VIANA, M. B. Avaliando minas: índice de sustentabilidade da mineração (ISM). 2012, $372 f$. Tese (Doutorado em Desenvolvimento Sustentável) Centro de Desenvolvimento Sustentável. Universidade de Brasília, Brasília, 2012.

WANDERLEY, L.J. Indícios de racismo ambiental na tragédia de Mariana: resultados preliminares e nota técnica. Universidade Estadual do Rio de Janeiro, 2015. 